\title{
Investing During the Recession: How County Governments Utilized Idle Cash
}

\author{
Steve Modlin \\ Adjunct Professor, East Carolina University \\ E-mail: swmodlin@gmail.com
}

Received: July 29, 2018 Accepted: August 7, 2018 Published: January 27, 2020

doi:10.5296/jpmr.v6i1.13439 URL: https://doi.org/10.5296/jpmr.v6i1.13439

\begin{abstract}
This article examines the investing practices of North and South Carolina county governments during the recession. Unlike many local governments across the country, county governments in both states reported that there were indeed funds available for investing at any given time. Initial findings indicate that investors were concerned for safety and liquidity as the local government investment pool (LGIP) for both states along with certificates of deposit (CDs) were the preferred instruments. Regression models of the four most widely used instruments were analyzed. Findings indicate lower property tax collections and an external primary bank of business were associated with higher LGIP investment; whereas, a significant relationship was also found between those with less experience and official educational background other than accounting and an increase in money market funds and federal government securities.
\end{abstract}

Keywords: local government investments, local government finance, county government

\section{Introduction}

The great recession proved to be quite challenging for local government officials. Diminishing revenue streams made service delivery problematic with officials examining various alternatives to both enhance revenue and reduce expenditures. The most notable adjustments were the reduction of unnecessary unencumbered expenses for operational items and the delay of capital projects. For larger governments, there was the option of possibly refinancing debt service projects. From a departmental standpoint, officials had to delay many requests for new or additional purchases and all parties had the task of maintaining efficiency with existing resources.

Finance officers were especially under intense scrutiny at the time. For local governments that were fortunate enough to have investments, careful scrutiny circumvented each decision. The literature thus far has provided little insight into the investment choices of government 
officials during the recession. The only thing for sure is that finance officers placed safety first when determining the utilization of idle cash (Modlin \& Stewart, 2013; Modlin, 2016). These same decisions also provide some information concerning official perception of recession duration due to the maturity dates of various instruments in relation to immediate expenses.

This exploratory study examines the investment practices of North and South Carolina County governments during the recession. Finance officers did indeed state that funding was available and invested at this time. The most popular choice was local government investment pools (LGIP), but also certificates of deposit (CDs) as well. A reduction of property tax dollars and the primary bank location outside of the county was significant with local government investment pool (LGIP) participation, while the presence of a cash management plan (CMP) and an increase in available funding was significant in determining participation in alternative securities.

This study adds key contributions to the literature in two very important ways. First, it examines investment practices of local governments during a critical time in local government finance. Very little information exists concerning cash management activity during this period, especially in cases of local government liquidity. Second, it provides a quantitative analysis of personnel decisions and organizational characteristics that play a role with instrument choice. Much of the previous research primarily consists of case studies or activity with one type of security with little information concerning official characteristics and the impact it may have on decision making.

\section{Investment Alternatives}

Local governments today generally have some sort of cash management policy (CMP). Some even take it a step further through the implementation of an actual investment policy. Additional endeavors have consisted of outsourcing investment activities to minimize costs (Stalebrink \& Sacco, 2006). In any case, the overall goal is public fund safety with objectives consisting of stable fund balance levels and a sustainable cash flow to provide uninterrupted service. Personnel responsible for investment decisions vary across jurisdictions. In some states, there is an elected trustee or treasurer that has both investment responsibilities and is responsible to the electorate while it is primarily the finance officer or other administrative officials in professionally administered governments (Modlin and Stewart, 2012). Communication is extremely important in cases with the elected official and administrators. Investment choices have to be determined in advance, especially in cases with a more intermittent cash flow forecast (Bland, 1986). For smaller governments, this has been found to be critical due to elected official voluntary actions concerning economic development ventures (Modlin, 2010). Guidance can be found within some state statutes and in situations with heavy state oversight over cash management practices (Coe, 1988; Miller, 1982).

Governments in this study primarily invested in four types of instruments. The most popular in recent years has been the local government investment pool (LGIP). The amount of research surrounding the use of investment pools has increased substantially over the past decade (Berry, 2008: Pantages, 2009; Modlin \& Stewart, 2013; Bland, Nukpezah, \& Shinkle, 
2015). In most cases, the pools primarily consist of the investments from multiple local governments in a single state with a minimum contribution amount. Pools can either be state-sponsored, a commingled effort of state and private entities, or independently managed by the participants. Investment pools provide increased flexibility for deposits and withdrawals with little or no penalty for frequent transactions and most have a AAAm bond rating from Standard \& Poors suggesting due to their ability to maintain principle and limited losses due to credit risk exposure (Modlin, 2016).

Certificates of Deposit (CDs) are bank time deposits. CDs are accompanied by a certificate stating the fixed rate of interest, the dollar amount, and the date of maturity. CDs can be negotiable and nonnegotiable and insured up to $\$ 100,000$ by the Federal Deposit Insurance Corporation against default. CD maturities are also quite elastic from week to a week to twelve months and up to five years for longer term CDs. Flexibility can also be achieved if the issuer allows redemption prior to the date of maturity. Also, the amount of CDs vary considerably at $\$ 1,000$ or more. Depending on the financial institution, some CDs can only be offered for a specified minimum. Nonnegotiable CDs actually have higher rates of return compared to negotiable CDs depending on interest and maturity rates. Most local governments do not authorize negotiable CDs due to collateralization and ownership substantiation.

Securities issued by the federal government are agency bonds (SEC). Two types of agency bonds exist for investment purposes. First, there are Government-Sponsored Enterprises (GSEs) that issue bonds on behalf of agencies that provide credit for various sectors of the economy. The bonds have shorter maturities and are not fully backed by the United States government, but yields are slightly higher than treasury bonds so there is some credit risk. Examples of GSEs include the Federal Home Mortgage Corporation and the Federal Agriculture Mortgage Corporation. Second, there are securities that are issued by government agencies. Unlike the GSEs, these bonds are backed by the full faith and credit of the United States government. The bonds usually have long-tem maturation dates and therefore not useful to many local governments. The Small Business Administration (SBA) and Government National Mortgage Association (Ginnie Mae) are just two agencies that issue securities.

Local governments in this study also widely utilized mutual funds as an investment tool (MM). Although mutual funds come in many forms, this sample primarily invested in high quality commercial paper. Both states have legislation specifying public fund safety as well as the maintenance of principle (NCGS 159-30, 1983; SC Code of Laws 12-45, 1976). Commercial paper is short, unsecured promissory note that has a short maturity of 270 days. Commercial paper is normally sold daily through dealers. States normally do not permit commercial paper investment, but for states permitting the practice, caution includes a regular review of ratings, rating outlooks, rating actions, and industry changes (North Carolina Department of State Treasurer, 2016).

\section{Previous Research}

Studies which have examined local government investment practices have primarily focused 
on state-sponsored local government investment pools. Initial research in this area suggested higher rates of return due to available funds, diversification within the portfolio, and full time managers (Thompson \& Gates, 1988; Strachota, 1991). Riskier investments by managers forced many states to re-examine portfolio investment practices (Bunch, 1999). Subsequently, many local governments have determined that the investment pool has become one of the most risk-free securities (Modlin \& Stewart, 2013; Kim, 2016). For portfolio purposes, it could be considered a risk-averse asset in some states (Tobin, 1958).

Very few studies have focused on investment activities from a comprehensive standpoint. In the late 1980s, Charles Coe (1988) performed a comparative analysis between local government investment practices in North Carolina and the North Carolina Local Government Commissions (LGC) newly implemented investment norms. Virtually all local government sizes increased the amount of invested funds after the guidelines were established. County governments, the basis of this study, were already investing more than $90 \%$ of idle funds. In particular, the state investment pool and CDs were the most popular option for investment as more than $80 \%$ of counties within the state with populations in excess of $25 \mathrm{~K}$ invested some funding in these two options.

Onwujuba and Lynch (2002) performed a comprehensive local government cash management study of 66 Louisiana municipalities with populations over $1 \mathrm{~K}$. The study examined virtually all phases of cash management from float reduction (bank services and relationships) to investment practices. As with the previous study, findings indicated that most cities preferred conservative instruments with more than $80 \%$ of cities with populations of $10 \mathrm{~K}$ or more investing in CDs. U. S. agency securities were also popular with municipalities with populations exceeding $100 \mathrm{~K}$ with more than $66 \%$ participating. Treasury securities were also popular with this group as nearly half invested in either a T-Bill or T-Note. In this study, there was no information given concerning a local government investment pool option.

Overall, previous research indicates safe investment choices, but substantial information concerning how these decisions are determined, especially during a critical time in history based on organizational characteristics has yet to be determined. Furthermore, there is little or no information concerning government or revenue capability that may actually influence these decisions.

\section{Data and Method}

To test for organizational and revenue factors associated with instrument investment, a mail survey was distributed to all county finance officers in North Carolina as well as South Carolina treasurers in 2009. After three rounds of survey dissemination, the response rate was approximately $54 \%$ or 79 responses. Small sample sizes such as this are indicative of many local government studies (Coe, 1988; Onwujuba \& Lynch, 2002; Modlin, 2011; Modlin \& Stewart, 2014). Respondents were asked to identify investment instruments from the list provided, the frequency of investment, and the amount of funds available for investment (FUNDS). Additional exploratory variables examined were finance officer experience (EXP), education level (ED), and primary field of study (FIELD). Also, identification of the designated investor was also requested (RESP). Since the responsibilities are primarily with 
the treasurer in South Carolina, further substantiation seemed appropriate.

Additional organizational predictors have some basis in the literature. The use of some type of competitive bidding or the use of an (RFP) for bank service solicitation was found to be significant for investment return purposes (Onwujuba \& Lynch, 2002). Part of the bank service package is collection methods as well as investment counseling. Depending on need, these issues need to be clarified in the RFP prior to disbursement in media outlets (Coe, 2007). Bank location itself (BANKLOC) has also found to be important as those outside the local are were found to provide a higher rate of return on investments and services (Modlin \& Stewart, 2012).

Revenue streams that influence cash availability are also expected to influence instrument choices. Considering the events of the time, the presence of a cash management policy (CMP) can assist with cash balance needs. Stone (1972) suggests if finance officers can more accurately determine future needs through forecasting, more flexibility can be added to already existing control limits. For idle cash purposes, the LGC recommends using fiscal data from the past three to five years be used to determine cash flow needs with subsequent investment of idle cash into appropriate instruments (North Carolina Department of State Treasurer, 1994).

The two largest revenue streams will also be used as predictors. First, the amount of property taxes as a percent of total revenue, are expected to be influential in determining investment activity. For many counties in this sample, it exceeded 50\%. Collection rates for counties in both states are also high and exceed 90\% annually (Modlin \& Stewart, 2013). Unless there is an immediate spending need at the beginning of the fiscal year when property taxes are disseminated, the funds can immediately be invested.

Sales taxes are the additional revenue stream which will be examined. Sales tax rates and uses vary considerably among counties with ranges from less than a percent to more than $18 \%$. Depending on the state, remittance monies can actually be immediately invested in the state investment pool prior to collection and expense payment. A higher amount of sales tax collections has been found significant leading to more investment pool participation (Modlin, 2016). Table 1 lists the predictors used in the analysis.

Table 1. Definitions of Variables for Measurement

\begin{tabular}{lll}
\hline Variable & Definition & Measurement \\
\hline CMP & The use of a cash management plan & $1=$ Yes \\
Funds & The amount of funds available for investment & $5=$ More than 10 million \\
EXP & Finance officer experience & $5=$ More than ten years \\
ED & Finance officer education level & $5=$ Ph.D. \\
FIELD & Finance officer educational training & $1=$ Accounting \\
Resp & Official responsible for investment decisions & $1=$ Finance Officer \\
RFP & The use of a RFP for bank service solicitation & $1=$ Yes \\
BANKLOC & Primary bank of service location & $1=$ Inside county \\
\hline
\end{tabular}


PROPERTY Property tax as a percent of total revenue

SALES
$3=$ More than fifty percent

$3=$ More than fifteen percent

For this particular study, the four most utilized instruments were used as dependent variables: the local government investment pools, CDs, federal government securities, and money market funds. The variables will be ordered according to the amount of funds invested in the instrument. For instance, if a local government invests more than $25 \%$ of idle funds in an instrument, it is coded ' 5 ' for the largest percentage invested in one instrument. Ordered logistic regression models will be constructed for each individual instrument and how the ten predictors influence the level of investment. Based on responses from finance personnel and data for the available revenue streams, the following base model has been constructed.

$$
\begin{aligned}
\text { INSTRUMENT }= & \beta_{0}+\beta_{1} C M P+\beta_{2} \text { FUNDS }+\beta_{3} E X P+\beta_{4} E D+\beta_{5} \text { FIELD }+\beta_{6} \text { RESP }+ \\
& \beta_{7} R F P+\beta_{8} \text { BANKLOC }+\beta_{9} \text { PROPERTY }+\beta_{10} \text { SALES }
\end{aligned}
$$

Since the study incorporates ordered dependent variables, a model is needed that can compensate for the varying level of responses which are a result of predictor changes as well as changes within the actual dependent variable. For instance, the random disturbance term $\left(\in_{i}\right)$, which has a logistic distribution suggests that LGIP investment, for instance, could easily fall somewhere between four and five (25\% invested) versus having a precise measurement.

$$
Y_{i}^{*}=\sum_{K=1}^{K} \beta_{K} \mathrm{X}_{k i}+\epsilon_{i}=\mathrm{Z}_{i}+\epsilon_{i}
$$

In sum, there are not many expectations concerning predictor direction. However, the revenue predictors (PROP, SALES) are expected to have a positive direction in the LGIP model, while an increase in available funds is expected to be positive in the federal government securities (SEC) and money market (MM) models. There is no prediction concerning the exploratory personnel predictors.

\section{Findings}

Previous research has demonstrated prudent decision making concerning instrument choices. A commingling of these practices and the uncertainty of the recession reduces risk even more. North Carolina county investment practices during the recession were indeed conservative (Table 2). Budget sizes notwithstanding, CDs and the LGIP were the primary instruments of choice. However, as a percentage of money available, officials preferred the LGIP. More than half of respondents stated investing more than $25 \%$ of available monies in the investment pool in 2009. One interesting finding among CDs was that nearly one-third of the smaller government sample (budget sizes of $<50 \mathrm{M}$ ) placed at least $5 \%$ of available funds in CDs. 
Although the type of CD maturity information was not solicited, durations were most likely limited.

Table 2. Instrument Investment by Budget Size

\begin{tabular}{|c|c|c|c|c|}
\hline Total $(n=79)$ & $\begin{array}{c}\text { Certificates of } \\
\text { Deposit }\end{array}$ & $\begin{array}{c}\text { Money Market } \\
\text { Funds }\end{array}$ & $\begin{array}{c}\text { Government } \\
\text { Securities }\end{array}$ & LGIP \\
\hline \multicolumn{5}{|l|}{ Budget Size } \\
\hline$>25 \mathrm{M}(\mathrm{n}=22)$ & 16 & 7 & 4 & 19 \\
\hline $25-50 M(n=19)$ & 16 & 10 & 3 & 20 \\
\hline $50 M-75 M(n=14)$ & 13 & 7 & 6 & 12 \\
\hline $75 \mathrm{M}-100 \mathrm{M}(\mathrm{n}=7)$ & 7 & 5 & 0 & 7 \\
\hline$<100 \mathrm{M}(\mathrm{n}=17)$ & 13 & 9 & 9 & 13 \\
\hline
\end{tabular}

Money market funds had similar interest from all government sizes in the sample. Nearly one-third of finance officers stated an investment of only $5 \%$ in this instrument while ten respondents among all government sizes stated a 25\% minimum investment. Federal government securities had the most interest of larger governments. For those that participated in these securities, more than $25 \%$ was invested.

Portfolio diversification was definitely present during the recession. Figure 1 provides some information concerning investment practices at this time. The chart is based on the highest frequency of responses based on percentage invested in an instrument. For example, if most counties stated investing at least $25 \%$ of idle funds in a security versus only $10 \%$, that is the representation illustrated. Based on additional data, county governments for this sample were investing a minimum of $40 \%$ of idle cash in state-sponsored investment pools (Modlin and Stewart, 2013). As mentioned earlier, the CD was utilized frequently, but most respondents only invested approximately $5 \%$ of available funds. Treasury securities and time deposits were also part of some investment portfolios, but less frequently compared to the other instruments and at only a $5 \%$ rate.

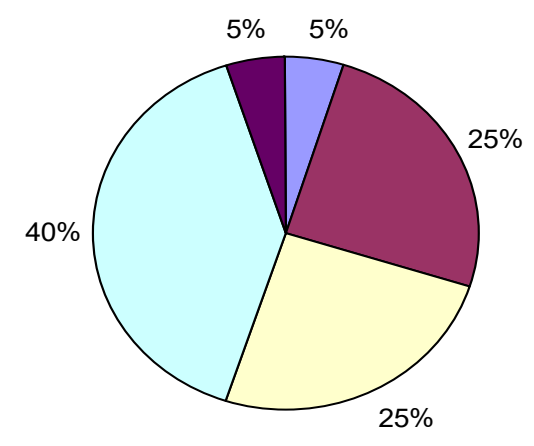

Figure 1. Portfolio Approximation of Largest Reported Percentage in Securities 
The portfolio diversification could also be a reflection of some of the descriptive statistics. Most of the county governments in the sample did have a CMP and a RFP for bank solicitation. Of course, for most counties, the primary bank of business was inside the county or local. The finance officer experience level with this sample was approximately 9-10 years and the primary occupational training was accounting. Interestingly enough however, the responsibilities for investment decisions varied considerably among government sizes. For governments with budget sizes of more than $\$ 50 \mathrm{M}$, it was overwhelmingly the finance officer; whereas, a combination of officials are the decision makers in smaller governments. In South Carolina, the elected treasurer is responsible for investment decisions for many counties, but most finance officers stated the responsibility is with multiple officials.

Table 3. Descriptive Statistics: Overall Sample (N=79)

\begin{tabular}{cccc}
\hline Variable & Mean & Standard Deviation & Range \\
\hline CMP & .825 & .382 & $0-1$ \\
Funds & 3.949 & 1.218 & $1-5$ \\
EXP & 3.925 & 1.199 & $1-5$ \\
ED & 2.875 & .769 & $1-5$ \\
FIELD & .600 & .493 & $0-1$ \\
RESP & .650 & .480 & $0-1$ \\
RFP & .813 & .393 & $0-1$ \\
BANKLOC & .888 & .318 & $0-1$ \\
PROPERTY & 1.737 & .737 & $1-3$ \\
SALES & 1.947 & .710 & $1-3$ \\
\hline
\end{tabular}

On average, the amount of funds available for investment approached $\$ 5 \mathrm{M}$. Larger governments benefited the most with most having more than $\$ 10 \mathrm{M}$ for investment purposes. However, governments with budget sizes between $\$ 25 \mathrm{M}-\$ 50 \mathrm{M}$ also stated having more than $\$ 10 \mathrm{M}$ available for investment. The fund balance requirement in North Carolina and the conservative governmental philosophy of many South Carolina council members and treasurers who have to answer to the public are part of this explanation. Sales tax revenue was nearly $10 \%$ of total revenue for the sample while property taxes approached $37 \%$.

Several ordered logistic models were constructed isolating the amount invested into the four most utilized instruments. The CD and MM models had somewhat similar findings as CMP and FUNDS had significant relationships with both instruments. CMP had a negative relationship with $\mathrm{CD}$ investment, but counties without a CMP were more than four times as likely to increase investment in money market funds. In both models, FUNDS was positive indicating that with an increase in the amount of revenue that was available for investment, the odds were two times more likely of a $5 \%$ or more investment increase into either of these securities. For the MM model, this increase was more than four times as likely to happen based on the odds ratio. Also with the MM model, the absence of a RFP for bank services 


\section{Macrothink}

Journal of Public Management Research

ISSN 2377-3294

2020, Vol. 6, No. 1

suggested an increase in commercial paper activity. Both models were significant at the .05 level indicating that the predictors provided reliable distinction between the differing levels of the dependent variables.

Table 4. Regression Analyses of Security Models

\begin{tabular}{|c|c|c|c|c|}
\hline Variable & CD Model & MM Model & SEC Model & LGIP Model \\
\hline CMP & $\begin{array}{c}-1.6140 \\
(.1991)^{* *}\end{array}$ & $\begin{array}{c}1.4789 \\
(4.3882)^{* *}\end{array}$ & $-.3315(.7179)$ & $-.0889(.9149)$ \\
\hline FUNDS & $.6598(1.9344)^{* *}$ & $.5047(1.6565)^{* *}$ & $.2487(1.2824)$ & $.2729(1.3138)$ \\
\hline EXP & .0119 (1.0119) & $.0505(1.0518)$ & $-.6756(.5089)^{* *}$ & $.2722(1.3128)$ \\
\hline ED & $.2432(1.2754)$ & $.1662(1.1808)$ & $.2293(1.2577)$ & $-.3078(.7351)$ \\
\hline FIELD & $-.1446(.8654)$ & $-1.2093(.2983)^{* *}$ & $\begin{array}{c}-1.9802 \\
(.1380)^{* *}\end{array}$ & $.1632(1.1772)$ \\
\hline RESP & $-.1824(.8333)$ & $-.3064(.7361)$ & $.4937(1.6384)$ & $.4233(1.5270)$ \\
\hline RFP & $.4671(1.5954)$ & $-1.2362(.2905)^{*}$ & $.6128(1.8456)$ & $\begin{array}{c}1.4395 \\
(4.2186)^{* *}\end{array}$ \\
\hline BANKLOC & $1.3534(3.8707)^{*}$ & $1.0426(2.8364)$ & $.2218(1.2483)$ & $-2.3508(.0952)^{* *}$ \\
\hline PROPERTY & $.2359(1.2661)$ & $.2819(1.3257)$ & $.1206(1.1282)$ & $-.7764(.4600)^{* *}$ \\
\hline SALES & $-.3058(.7366)$ & $-.3859(.6798)$ & $-.2423(.7849)$ & $-.1721(.8419)$ \\
\hline Threshold 1 & 1.5467 & 2.7825 & -.2315 & -3.2008 \\
\hline Threshold 2 & 3.2763 & 3.8558 & .3083 & -2.4260 \\
\hline Threshold 3 & 3.7076 & 4.5581 & .4289 & -2.0048 \\
\hline Threshold 4 & 4.2652 & 4.6823 & .5632 & -1.5624 \\
\hline Threshold 5 & 4.7302 & 4.8132 & 1.4508 & -1.3558 \\
\hline $\mathrm{N}$ & 76 & 76 & 76 & 76 \\
\hline Log Lik. & -106.5395 & -80.3616 & -54.7222 & -87.4107 \\
\hline LR Chi-squared (10) & $17.50^{*}$ & $19.67 * *$ & 14.57 & $16.73^{*}$ \\
\hline $\begin{array}{l}\text { McFadden's } \\
\text { Pseudo-R }\end{array}$ & .0759 & .1090 & .1175 & .0873 \\
\hline
\end{tabular}

Notes: Cell entries are unstandardized parameter estimates; ${ }^{* *} p \leq .05 ;{ }^{*} p \leq .10$ (two-tailed test).

(Odds ratios in parentheses)

Predictor relationships in the final two models had various findings. Less experienced finance officers and officials with a background in a field besides accounting were more likely to invest in government securities. The FIELD finding was also significant in the MM model; however, the small odds ratio indicated a modest change with investment based on educational background. The LGIP model had more conventional findings. Investing in the 
local government investment pool dropped by .7764 when property tax revenue decreased by approximately $10 \%$ given the other variables in the model were held constant. RFP and BANKLOC contradicted previous models. RFP was significant and positive suggesting a high likelihood of LGIP investment if that process was used in bank solicitation; whereas, the predictor was negative in the MM model. An external bank location for primary services suggested less LGIP investment, but a local bank suggested more CD participation. These findings were not that unusual since the largest counties in the sample were the most likely to have a primary bank of business outside the presiding county.

\section{Conclusion}

This exploratory study has examined the investment practices of county governments during the recession isolating instrument participation against personnel characteristics, policy practices, and revenue streams. It was a given that finance officers were interested in risk averse instruments and predictors in various models provided some support, but it appears that in some cases it could be omitted information that may have determined the instrument. For instance, a more professional process for bank service solicitation and a reduction of property tax revenue increased LGIP participation; whereas, the lack of a CMP and a local bank for services and increased funding led to $\mathrm{CD}$ participation. It can therefore be concluded that finance officers in larger governments that are aware of market and instrument behavior immediately invested available monies in the LGIP for risk averse reasons while governments that do not have as much information due to smaller staffs relied on the CD more heavily. A previous finding suggests that in many cases, finance officers immediately send state sales tax remittance monies to a LGIP (Modlin \& Stewart, 2013). Background educational training and experience also provide evidence for these activities. Officials with backgrounds in accounting were much more likely to invest in the LGIP or a CD compared to officials with more diverse backgrounds. Even the experience predictor was significant in the SEC model indicating more experienced finance officers chose have less participation in federal government securities.

The findings had consistency with previous findings as well. First, Similar to the Coe (1988) study, the LGIP and CD were the preferred investment options. Second, larger governments in this study also had substantial preference for federal government securities similar to Onwujuba and Lynch (2002). Third, administrator decision making appeared to be based on uninterrupted cash flow so that basic service needs could be met (Guo, 2017). Of course, the substantial amount of revenue available for investment can mitigate potential losses, especially with the availability of a sound investment pool (Shipway, 2009).

There are some limitations with the study. First, data was not available for the period prior to the recession for comparison purposes. More than likely, more diversification would have been present, especially for larger governments; however, due to the consistency with previous studies and the state oversight processes and political philosophies, substantial contrasts would more than likely be isolated. Second, there was no isolation of officials that have specific responsibilities for investment compared to overall financial responsibilities. In both states, many of these responsibilities were a collaboration of personnel versus one individual. Even in larger governments, the finance officer may delegate these responsibilities 
to other finance staff. Third, due to the need for the survey tool to be user-friendly, there was no isolation of maturity dates for various securities. For instance, low maturation dates for CDs, government securities, and money market securities in addition to the frequency of LGIP withdrawal would provide some insight into cash flow at the time. Fourth, widespread commissioner or council input concerning investments would have provided some interesting results, especially for boards that have members with business backgrounds.

Finance officers were faced with the major task of obtaining as much revenue as possible during the recession. The findings have demonstrated an overall effective management of funds with minimal risk investment alternatives while eliminating expenses during service delivery. The difficulties of the recession were very challenging for many local governments, but officials in this sample demonstrated the necessary management skills needed to meet a fiscal crises challenge.

\section{References}

Berry, C. (2008). Piling On: Multi-level Government and the Fiscal Common- Pool. American $\begin{array}{lll}\text { Journal of } & \text { Political } & \text { Science, }\end{array}$ https://doi.org/10.1111/j.1540-5907.2008.00344.x

Coe, C. K. (2007). Government and Nonprofit Financial Management. Vienna, Virginia: Management Concepts.

Coe, C. K. (1988). The Effects of Cash Management Assistance by States to Local Governments. Public Budgeting \& Finance, 8(2), 80-90. https://doi.org/10.1111/j.1540-5907.2008.00344.x

Bland, R. L. (1986). The Effect of Cash Management Innovations on the Investment Income of Local Governments. State and Local Government Review, 18(1), 20-25.

Bland, R. L., Nukpezah, J. A., \& Shinkle, P. (2015). Determinants of Depositor Demand for the Texas Local Government Investment Pool. Public Budgeting \& Finance, 35(3), 95-115. https://doi.org/10.1111/j.1540-5907.2008.00344.x

Bunch, B. (1999). Texpools's Experiences in the 1990s: Policy Implications for Other State Investment Pools. Public Budgeting \& Finance, 19(4), 21-34. https://doi.org/10.1046/j.0275-1100.1999.01176.x

Guo, Z. (2017). Health Insurance and the Demand for Medical Care: A Case Study from China. Asian Journal of Economics and Empirical Research, 4(1), 8-13. https://doi.org/10.20448/journal501.2017.41.8.13.

Kim, J. (2016). Return of Money or Return on Money? Analyzing the Asset Concentration of Local Government Investment Pool Portfolios. Journal of Budgeting, Accounting, \& Financial Management, 28(1), 1-25. https://doi.org/10.1108/JPBAFM-28-01-2016-B001

Miller, G. (1982). A Public Investor's Guide to Money Market Instruments. Chicago: Municipal Finance Officer's Association.

Modlin, S. (2016). Getting All You Can: County Government Investment Pool Participation 
Based On Need or Want. Public Administration Quarterly, 40(4), 949-970.

Modlin, S. (2010). State Enhancement of Local Government Decision Making in the Budgetary Process: A Model for State Oversight of Local Government Finances. Public $\begin{array}{llll}\text { Performance \& } \quad \text { Management Review, 33(4), } & \text { 571-593. }\end{array}$ https://doi.org/10.2753/PMR1530-9576330403

Modlin, S. (2011). Who Really Runs County Government? The County Manager in the Budget Formulation Process. Public Administration \& Management, 16(12), 21-45.

Modlin, S., \& Stewart, L. (2013). Assessing Participation in the State-Sponsored Local Government Investment Pool During the Recession: An Examination of North Carolina Counties. Public Budgeting \& Finance, 33(4), 90-106. https://doi.org/10.1111/j.1540-5850.2013.12024.x

Modlin, S., \& Stewart, L. (2012). Cash Management Practices Among Southeastern County Governments: Proper Utilization or Excessive Caution. Public Finance and Management, 12(2), 100-119.

Modlin, S., \& Stewart, L. (2014). Determining County Government Fiscal Instability: Independent Audit Report Findings and the Prompting of State Action. Journal of Public Budgeting, Accounting \& Financial Management, 26(3), 405-428. https://doi.org/10.1108/JPBAFM-26-03-2014-B002

North Carolina Department of State Treasurer. (2009). County and municipal information. Retrieved June 10, 2010, from http://www.nctreasurer.com/lgc/units/ unitlistjs.htm)

North Carolina Department of State Treasurer. (1994). Local Government Cash Policy Manual.

North Carolina Department of State Treasurer. (2016). Policy Manual for Local Governments, "Section 30: Cash and Investments: 55."

North Carolina General Statute. (2007). 159-30@(6).

Onwujuba, C. C., \& Lynch, T. D. (2002). Cash Management Practices in Louisiana Municipalities. Journal of Budgeting, Accounting, \& Financial Management, 14(1), 95-116. https://doi.org/10.1108/JPBAFM-14-01-2002-B005

Pantages, P. (2009). Local government Investment Pools and the Financial Crises: Lessons Learned. Government Finance Review, 25(5), 18-24.

Shipway, I. (2009). Modern Portfolio Theory. Trust \& Trustees, 2(15), 69. https://doi.org/10.1108/JPBAFM-26-03-2014-B002

Strachota, D. (1991). State Involvement in Local Government Finance. In J. E. Petersen \& D. R. Strachota (Eds.), Local Government Finance, Concepts, and Practices (pp. 434-454). Chicago: Government Finance Officers Association.

South Carolina Code of Laws (1976). Section 12-45. 


\section{Macrothink}

Journal of Public Management Research

ISSN 2377-3294 2020, Vol. 6, No. 1

South Carolina State Budget \& Control Board. (2009) Office of Research \& Statistics, Local Government Finance Report. Retrieved June 10, 2010, from http://www.sccounties.org/services/Research/budgets-and-cafrs.aspx

Stalebrink, O. J., \& Sacco, J. F. (2006). Public Sector Investment Failures: Theoretical Contributions from New Institutional and Austrian Economic Theory. Journal of Budgeting, Accounting, \& Financial Management, 18(3), 351-375. https://doi.org/10.1108/JPBAFM-18-03-2006-B005

Stone, B. K. (1972). The Use of Forecasts and Smoothing in Control-Limit Models for Cash Management. Financial Management, 72-84.

Thompson, F., \& Gates, B. L. (1988). Estimating the Liquidity Requirements of Cash Pools. State \& Local Government Review, 20(3), 105-112.

Tobin, J. (1958). Liquidity Preferences as Behavior Towards Risk. Review of Economic Studies, 26, 65-68.

\section{Copyright Disclaimer}

Copyright for this article is retained by the author(s), with first publication rights granted to the journal.

This is an open-access article distributed under the terms and conditions of the Creative Commons Attribution license (http://creativecommons.org/licenses/by/4.0/). 